\title{
Optimizing the process parameters during friction stir welding on AA2024 weld joints using Taguchi method
}

\author{
Md Mastan $\mathrm{Ali}^{1}$, M. S. Srinivasa Rao ${ }^{2}$ \\ ${ }^{\text {I}}$ (PG student, Mechanical Department, VNR VJIET / JNTUH, India) \\ ${ }^{2}$ (Assistant Professor, Mechanical Department, VNR VJIET /JNTUH, India)
}

\begin{abstract}
FSW (friction stir welding) is a solid state joining technique winch Is use for similar and dissimilar alloys which has been used in defence, aerospace, marine and industires. The AA2024 is a heat treatable alluminum alloy finds wide application in defence and Aerospace due to its high strength to weight ratio. The rotational speed, traverse speed and different tool pin profiles as taper square, taper pentagon, taper hexagon are the parameters taken into consideration to weld $6.4 \mathrm{~mm}$ of AA2O24 thick plate by using AISI H13tool. The tensile strength, yield strength, \% of elongation is carried out to know the effect of process parameters on the weld joints, and taguchi method is used to analyse the obtained values. The better value is obtained at rotaional speed 1000rpm, traverse speed $30 \mathrm{~mm} / \mathrm{min}$. Taguchi method is used to minimize the number of experiments, time and cost.
\end{abstract}

Keywords: Analysis of variance, FSW, Tensile strength, yield strength, \% of elongation.

\section{Introduction}

Friction Stir Welding (FSW), an innovative solid state welding technique, now a day's this method is widely using in defence and aerospace applications. This method is environmentally free and energy efficient method can be used to join high strength aluminum alloys and other materials that are difficult to weld using conventional welding process [1]. FSW is a mechanical process were two plates were joined by creating a friction between the plates, a tool is used to create the friction and it takes place in the solid phase, the welding defects related to the solidification of a material are avoided, and thermal efficiency of friction stir welding is almost $90 \%$ and above [2]. Frictional heat is generated by the welding tool which is penetrated into the base material and surrounding of material causes softening the material and allows the tool to move along the weld line initially, the AA2024 is plasticized, and it is transferred from the leading edge of the tool, leaving a solid bond between the weld plates [3].

The friction stir welding is process based on the parameters mainly on rotational speed and traverse speed which creates the frictional heat, if any defects were occurred during the FSW process it cannot eliminated, whereas in conventional welding it can be corrected by reworking of the material [4]. The weld zone, Thermo Mechanically Affected Zone (TMAZ) and Heat Affected Zone (HAZ) are the regions of the friction stir welding plate regions across the width of weld joints. The friction stir welding is the single pass welding process to fabricate the similar and dissimilar materials [5]. Most of the areas steels were replaced by aluminum and nonferrous alloys. Change of material is happening due to its low weight and having almost all equal mechanical properties with steels. Joining of these materials with conventional welding method causes defects, FSW, is a solid state welding process which is used to overcome the defects appearing in welding of these materials [6]. Non consumable tools made of AISI H13 steel tool to weld the aluminum alloy AA2024. In this investigation, found that the tool pin profile is the main factor for affecting the weld joints. The aluminum alloy used in this process is AA2024 has it is widely used in aerospace, marine industries in the construction of pipelines, storage tanks and frames [7]. The FSW process parameters and tool pin profiles are the main factors affecting the weld joint.

\section{Experimental Procedure}

The material used in this investigation is $6.4 \mathrm{~mm}$ thick plate of aluminum alloy 2024 , and the chemical compositions and mechanical properties for AA 2024 were shown in Table 1 and Table 2. The weld plates were cut into dimension of $[200 \times 100 \mathrm{~mm}]$ into rectangular samples and the welding was carried out using CNC vertical milling machine as shown in "Fig 1". The AISI H13 welding steel tool is used in this investigation. The different tool pin profiles were used and they are Taper Square, Taper Pentagon, and Taper Hexagon as shown in "Fig 2". The process parameters and the results obtained are shown in below Table 3 according to the sequence level of experiments. The samples were prepared according to ASTM E8 standards for mechanical properties; UTM (universal testing machine) is used to carry out the results of AA2024. 
Optimizing the process parameters during friction stir welding on AA2024 weld joints using ...

Table 1: AA2024 composition of Al-Alloys

\begin{tabular}{|c|c|c|c|c|c|c|c|c|c|}
\hline Al-Alloy & $\begin{array}{c}\mathrm{Mg} \\
\%\end{array}$ & $\mathrm{Cu} \%$ & $\begin{array}{c}\mathrm{Si} \\
\%\end{array}$ & $\mathrm{Zn} \%$ & $\begin{array}{c}\mathrm{Mn} \\
\%\end{array}$ & $\begin{array}{c}\mathrm{Cr} \\
\%\end{array}$ & $\begin{array}{c}\mathrm{Ti} \\
\%\end{array}$ & $\begin{array}{c}\text { Specific heat } \\
\mathrm{J} / \mathrm{g}{ }^{\circ} \mathrm{C}\end{array}$ & $\begin{array}{c}\text { Thermal } \\
\text { conductivity W/m-k }\end{array}$ \\
\hline AA2024 & 1.514 & 4.307 & 0.043 & 0.095 & 0.494 & 0.005 & 0.054 & 0.86 & 121 \\
\hline
\end{tabular}

Table 2: AA2024 Mechanical properties

\begin{tabular}{|c|c|c|c|c|}
\hline Material & Tensile Strength N/mm2 & Yield Strength N/mm2 & \% of Elongation & Hardness (HV 0.5) \\
\hline AA2024 & 472.4 & 384.168 & 17.54 & 127.5 \\
\hline
\end{tabular}

Table 3: AA2024 Process parameters for FSW

\begin{tabular}{|c|l|c|c|c|c|c|}
\hline Material & Tool profile & $\begin{array}{c}\text { Rotational } \\
\text { speed } \\
(\mathrm{rpm})\end{array}$ & $\begin{array}{c}\text { Traverse } \\
\text { speed } \\
(\mathrm{mm} / \mathrm{min})\end{array}$ & $\begin{array}{c}\text { Tensile } \\
\text { Strength } \\
\text { N/mm2 }\end{array}$ & $\begin{array}{c}\text { Yield } \\
\text { Strength } \\
\text { N/mm2 }\end{array}$ & $\begin{array}{c}\text { \% of } \\
\text { Elongation }\end{array}$ \\
\hline AA2024 & Taper square & 1000 & 20 & 290.73 & 265.97 & 11.4 \\
\hline AA2024 & Taper pentagon & 1000 & 30 & 284.48 & 257.00 & 12.2 \\
\hline AA2024 & Taper hexagon & 1000 & 40 & 297.09 & 270.69 & 14.5 \\
\hline AA2024 & Taper pentagon & 1200 & 20 & 241.37 & 210.44 & 13.2 \\
\hline AA2024 & Taper hexagon & 1200 & 30 & 327.155 & 291.62 & 14.1 \\
\hline AA2024 & Taper square & 1200 & 40 & 154.61 & 132.61 & 9.6 \\
\hline AA2024 & Taper hexagon & 1400 & 20 & 173.65 & 141.47 & 12.9 \\
\hline AA2024 & Taper square & 1400 & 30 & 205.08 & 178.46 & 13.9 \\
\hline AA2024 & Taper hexagon & 1400 & 40 & 278.45 & 246.18 & 13.0 \\
\hline
\end{tabular}

The tool pin profile geometry is taken from the relation between the pin length, profile diameter and shoulder diameter as showing in Table 4, and 140 of taper angle is taken for pin profile as shown on "Fig 2".

Table 4: Formulas for Tool Geometry

\begin{tabular}{|c|c|c|}
\hline Pin profile length $(\mathrm{mm})$ & $\begin{array}{c}\text { Pin profile diameter } \\
(1 \text { to } 1.5 \varnothing)\end{array}$ & $\begin{array}{c}\text { Shoulder Diameter } \\
\text { (2d to 3d } \varnothing)\end{array}$ \\
\hline $0.96 \times$ material thickness $(\mathrm{mm})$ & $1.25 \times$ pin length $(\varnothing)$ & $2.25 \times$ pin profile diameter $(\varnothing)$ \\
\hline
\end{tabular}

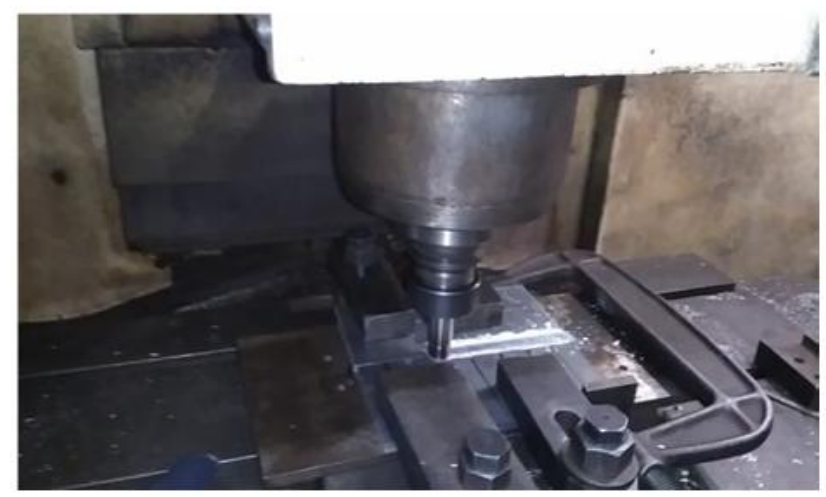

Fig 1: Set up for friction stir welding

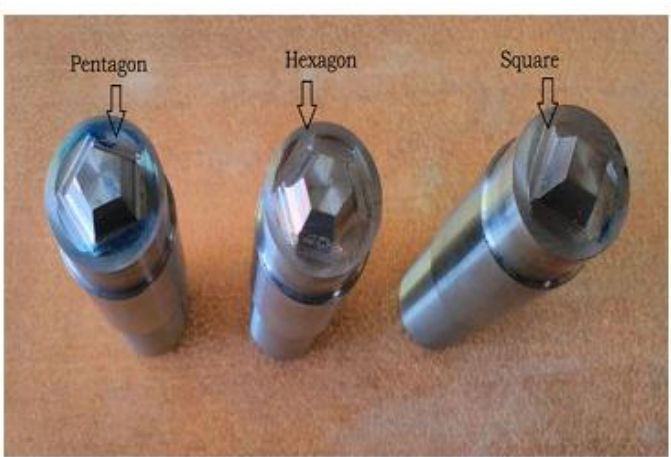

Figure 2: a) Tool pin profiles before weld

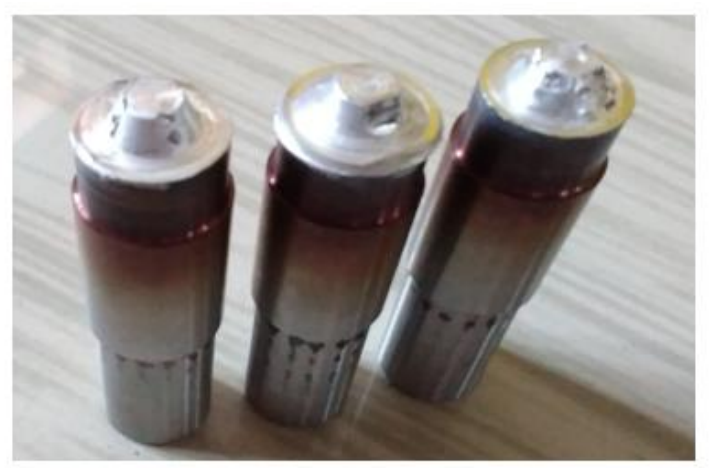

b) Tool pin profiles after weld 
The tool geometry has major impact on the weld strength due to the shoulder diameter and pin diameter as they were not in the ratio of D/d that is 1:3. Due to this a linear kissing bond, tunnel defect is found on the weld and blow holes are observed. The material is stick to the tool due to the variation of the axial load and insufficient load is acted on the weld plates due to this the material is stick to the tool profiles and a defects were observed during the welding.

\subsection{Design of experiments}

The process parameters were considered for this investigation as rotational speed $\mathrm{rpm}$, traverse speed $\mathrm{mm} / \mathrm{min}$ and tool pin profiles and their levels as show in Table 2.

\subsection{Genichi taguchi method}

Genichi taguchi method is used for designing the number of experiments for a system. This method the number of experiment is reduced to 9. The degree of freedom is calculated to choose the correct orthogonal array. The DOE (degree of freedom) is 8 for L9 orthogonal array and nine experiments were conducted for friction stir welding as per Taguchi L9 orthogonal array [5].

\section{$2.3 \mathrm{~S} / \mathrm{N}$ ratio}

Taguchi method is used to analyze the optimal process parameters by $\mathrm{S} / \mathrm{N}$ ratio method. This method helps in identifying the significant values for finding the optimal parameters.

\subsection{Tensile Strength}

\section{Results And Discussion}

The tensile strength is the maximum stress that a material can with stand while stretched or pulled before breaking. Tensile test of AA2024 was carried out according to ASTM E8 standards, here we use larger the better $\mathrm{S} / \mathrm{N}$ ratio to know the effect of the process parameters on the weld joints as shown in Table 5.

Table 5: AA2024 S/N Response table for Tensile Strength.

\begin{tabular}{|l|l|l|l|}
\hline Level & Speed & Feed & Tool \\
\hline 1 & $\mathbf{4 9 . 2 7}$ & 47.24 & 46.43 \\
\hline 2 & 47.24 & $\mathbf{4 8 . 5 4}$ & $\mathbf{4 8 . 5 4}$ \\
\hline 3 & 46.64 & 47.38 & 48.18 \\
\hline Delta & 2.63 & 1.30 & 2.11 \\
\hline Rank & 1 & 3 & 2 \\
\hline
\end{tabular}

From Table 5, we can conclude that at rotational speed $1000 \mathrm{rpm}$ and traverse speed at $30 \mathrm{~mm} / \mathrm{min}$ and taper pentagon tool has the high tensile strength values. "Fig 3" shows the main effects plot of tensile strength.

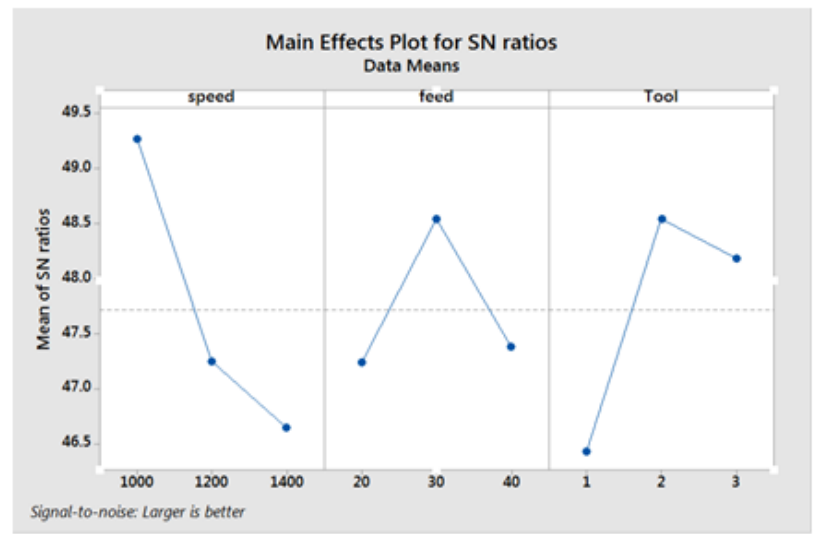

fig 3: AA2024 Main effects plot for tensile strength

\subsection{Yield Strength}

Yield strength is the material property at which a material begins to deform plastically. Therefore $\mathrm{S} / \mathrm{N}$ ratio larger the better is used to know the effect of parameters on the yield strength and the values are placed in Table 6. 
Table 6: AA2024 S/N Response table for yield strength

\begin{tabular}{|l|l|l|l|}
\hline Level & Speed & Feed & Tool \\
\hline 1 & $\mathbf{4 8 . 4 5}$ & 45.99 & 45.33 \\
\hline 2 & 46.07 & 47.51 & $\mathbf{4 7 . 5 0}$ \\
\hline 3 & 45.29 & $\mathbf{4 7 . 3 1}$ & 46.99 \\
\hline Delta & 3.16 & 1.52 & 2.17 \\
\hline Rank & 1 & 3 & 2 \\
\hline
\end{tabular}

From Table 6, we can conclude that at rotation speed $1000 \mathrm{rpm}$, traverse speed at $40 \mathrm{~mm} / \mathrm{min}$ and taper pentagon tool has the high Yield strength value as shown in "Fig 4".

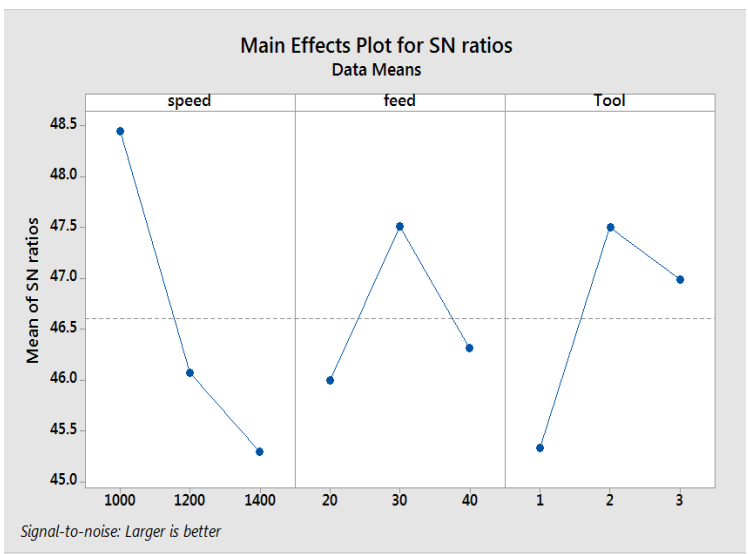

fig 4: AA2024 Main effects plot for Yield strength

\subsection{Percentage of Elongation}

The optimum process parameters obtained for $\%$ of elongation is at the rotational speed of 1000rpm and traverse speed of $40 \mathrm{~mm} / \mathrm{min}$ and the tool pin profile is taper hexagon tool as shown in the below graph "Fig 5" and the table 7.

Table 7: AA2024 S/N response table for \% of elongation

\begin{tabular}{|l|l|l|l|}
\hline Level & Speed & Feed & Tool \\
\hline 1 & 22.05 & 21.96 & 21.24 \\
\hline 2 & 21.70 & 22.52 & 22.15 \\
\hline 3 & 22.46 & 21.72 & 22.82 \\
\hline Delta & 0.76 & 0.80 & 1.58 \\
\hline Rank & 3 & 2 & 1 \\
\hline
\end{tabular}

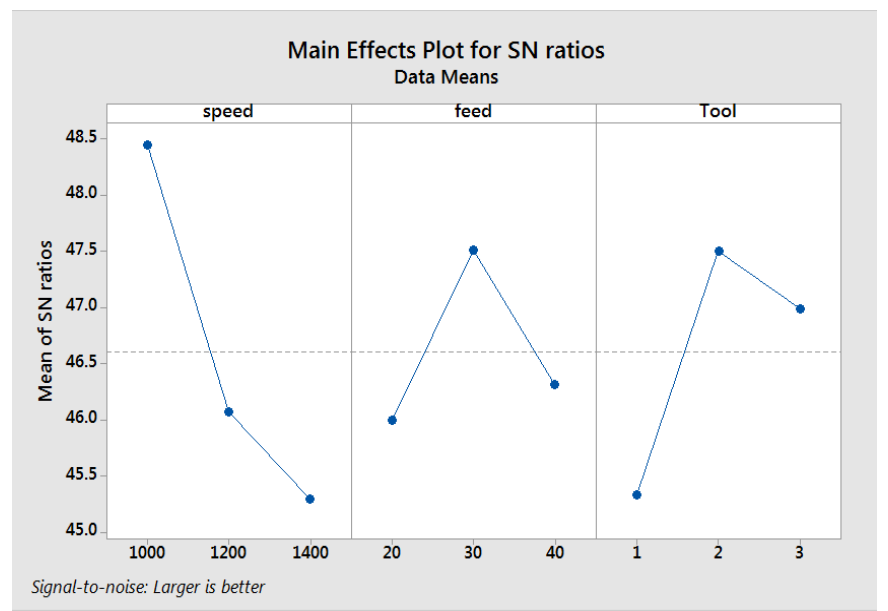

Fig 5: Mean of SN ratio plot for \% elongation 


\section{Conclusion}

In this investigation, Taguchi method is used to analyses the optimal parameters for FSW of AA2024. The results can be drawn as follows

$>$ The results include that the shape of tool pin profile has the main effect on the weld joints and the better result is obtained to the tapered hexagon tool pin profile.

$>$ The rotational speed, traverse speed as impact on the weldments. The higher the rotational speed and lower the traverse speed gives the better joints.

$>$ Fig 3,4,5 shows the optimal values and got the better mechanical properties at rotational speed of $1000 \mathrm{rpm}$ and traverse speed $30 \mathrm{~mm} / \mathrm{min}$ to taper pentagon tool pin profile.

$>$ The highest tensile strength is got at the rotational speed of $1200 \mathrm{rpm}$, traverse speed of $30 \mathrm{~mm} / \mathrm{min}$ to taper hexagon tool profile.

$>$ From the above results I can conclude the optimal value as traverse speed $30 \mathrm{~mm} / \mathrm{min}$ which gives the better results to taper pentagon and taper hexagon tool profiles at rotational speed of $1000 \mathrm{rpm}, 1200 \mathrm{rpm}$.

\section{Acknowledgements}

I would like to express my heartfelt thanks to my institution VNRVJIET, Hyderabad; I would like to convey my sincere thanks to Mr. M. S. Srinivasa Rao, Guide and Assistant Professor in Mechanical Engineering, VNRVJIET, for his precious guidance, at every step of this project work. I would also like to thank GPM industries, Hyderabad for allowing us to perform friction stir welding.

\section{References}

[1]. Ch Venkata rao, G Madhusudhan reddy and K. Srinivasa Rao, Microstructure and pitting corrosion resistance of AA2219 Al-cu alloy friction stir welds - effect of tool profile, Defence Technology, Vol.11, pp. 123-131, 2015.

[2]. Catarina Vidal, Virginia Infante and Pedro Vilac, Assesment of improvement techniques on fatigue behavior of friction stir welded aerospace aluminum alloy, Procedia Engineering, Vol. 2, pp. 1605-1616, 2010.

[3]. Avinash P, Manikandan M, Arivazhagan N, Devendranath Rakumar K and Narayanan, Friction stir welded joints of AA2024T3 and AA7075 T6 aluminum alloys, Procedia Engineering, Vol. 75, pp. 98-102, 2014.

[4]. R. Padnaban, V. Ratna Kishore and V. Balusam, Numerical simulation of temperature distribution and material flow during friction stir welding of dissimilar aluminum alloys, $12^{\text {th }}$ Global congress on manufacturing and management, Procedia Engineering, Vol. 97, pp. 854-863, 2014.

[5]. C. Elanchezhian, B. Vijaya Ramnath, P. Venkatesan, S. Sathish, T. Vignesh, R. V. Siddharth, B. Vinay and K. Gopinath, Parameter optimization of friction stir welding of AA8011-6062 using mathematical method, $12^{\text {th }}$ Global congress on manufacturing and management, Procedia Engineering,Vol.97, pp. 775-782, 2014.

[6]. G. Rambabu, D. Balaji Naik, C. H. Venkata Rao, K. Srinivasa Rao and G. Madhusudan Reddy, Optimization of friction stir welding parameters for improved corrosion resistance of AA2219 aluminum alloy joints, Defence Technology. Vol. 11, pp. 330-337, 2015.

[7]. Sadeesh P, Venatesh Kannan M, Rajkumar V, Avinash P, Arivazhagan N, Devendranath, Ramkumar K and Narayanan S, Studies on friction stir welding of AA2024 and AA6061 dissimilar metals, $7^{\text {th }}$ international conference on materials for advanced technology, Procedia Engineering, Vol. 75, pp. 145-149, 2014.

[8]. M. Mehta, G. M. Reddy, A.V. Rao and A. De: Numerical modeling of friction stir welding using the tools with polygonal pins, Defence Technology, 11, 2015, pp. 229-236.

[9]. Pasquale Cavaliere, Friction stir welding of Al alloys; analysis of processing parameters affecting mechanical behavior, $2^{\text {nd }}$ international through-life engineering services conference, Procedia CIRP, Vol. 11, pp. 139-144, 2013.

[10]. Prof. S. K. Aditya and Mr. Abhijit Datta, Analysis of friction stir welding of aluminum alloys and optimization of welding parameters for maximum tensile strength, ijera, Vol. 5, pp. 36-43, 2015. 